\title{
Batak Toba Concept of A Leader in Umpasa and Umpama
}

\author{
Martha Pardede ${ }^{1}$, Roswita Silalahi ${ }^{2}$ \\ \{pardede.martha@yahoo.com\} \\ 12 Sastra Inggris, FIB, Universitas Sumatera Utara, Padang Bulan 20155, Indonesia
}

\begin{abstract}
Umpasa and umpama are two kinds of literary works that belong to the people of Batak Toba that reflect briliant thoughts, collective conciousnes and life philosofie of the traditional of Toba Batak that lead the way of thinking and the way of life of the people. They are parts of the identity of the people. As the identity of the people it is important to learn it to enable peole to establish reconciliation with the digital revolutionary world.The objective of the research is to answer the question wether the traditional concept of a leader should be obseleted or not by analysing and finding the hidden meaning of umpasa and umpama which deal with the concept of Batak Toba of a leader.The research had to pay attention to the social cultural aspects of the people of Batak Toba byusing qualitative descriptive method.Th finding shows that the meaning within umpasa and umpama deal with the concept of a leader still relevant with the modern theories in digital era.
\end{abstract}

Key words : umpama, umpasa, leader, society .

\section{Introduction}

The flow of globalization destroys the cultural values and social characters especially the character of the young generation in cities and at rural areas in Indonesia. Cultural values which cover the entire meaning of that social values such as knowledge, social structure which actually were the result of human struggle. In this open source of the 21 st century, the traditional management and business models have been transformed into digital technology. According to Nasir [1]. The expert claim that we are in the middle of digital revolution as it is chasing this world as such profound the speed. This problem creates the shift of social structure and increase the process of interconnection among the people. It is a multi demension problem as can be found in political, social cultural, economy and defence aspect. On the other side many nations have proved that loving and conciousnes of cultural values from the past are a huge shield in achieving the progress. Just take a look on what have been done by Japan, Cina, India and Korea. They are able to overcome the problems they encounter by using their traditional values.

It is true that the development of technology brings with it many positive results. Still we have to agree with the contrast idea that says that many precious traditional value such as the concept of a good leader have disappeared from the social life. The result of previous research on umpasa and umpama shows that many of them contain local genious deal with politic such 
as the characters that should be owned by a leader. Therefore, the research is highligting some traditional concept of a leader which are suitable and need to be considered for reshaping today's leader in the open source era of technology.

The difficulties of drawing attention to the value found in traditional heritage happen all over the etnic groups in Indonesia. This research tries to give answers to the effort of revitalising local genious. Local genious according to Hilman [2] " Local wisdom is one ofthe product of cultural community that formed because the necessary of value norm and rule s a model to do something action". Haryati Soebadoi [3] gives a definitin of local wisdom "... as an identity or cultural personality of a nation that make the nation able to absorb and cultivate culture which come from outside suitable to the character and personal need. On another aspect, this ability even named as tenacity, mainly on cultural field or what tenacity of nation we call to day as nation tenacity of each nation"

After modernization then came the era of post modernism, the now time where we live . The era is not about logic and substance any more. It is about style and perception. In its extrim form, there is no absolute truth anymore. Human live in cultural market, the place for idea, perspective or point of view like box office movie, politic and advertisementthat destroy the concept of the truth and present confusion in outority that claim the truth. All of them are the impacts of the failure of nowledge in giving solution for the problem.Still,we do not need to e worry as long as we are ready to hold the traditional value as a system of knowledge.

Tobing and Hutabarat [4] say "That Bataknese Toba tribe located in North Sumatera Province is one that still retain the tradition passed down from generation to generation by their ancestor."

According to Samosir [5] "The Toba Batak Language, the language spoken by Toba Batak people is included in the Malay language family which has a typical grammar system and its own meaning. The Toba Batak language is unique, poor in words which can explain the general, very rich in thos, that diffrenciate the particular. For example, it has no word for monkey in general. But it has name for each particular kind of monkey" According to Sidabutar [6] "Batak culture which was the root of the Batak society had essential part in character build of the leader in Indonesia." And according to Reed [7] "Batak of North Sumatera are one of the Indonesian most important intrique group in Indonesia" The benefit of conducting this research is to drawthe attention of the people to the cultural element like umpasa and umpama and to motivate other researcher to conduct the same research on the cultural element of hundreds etnic group in Indonesia which in the same time empowered the social identity of Indonesia as a nation. The formulation of the problem is to find out the concept which are categorized political that is the concept of Batak Toba of a leader by finding the deep meaning of umpasa and umpama. According to Pasaribu A.N [8] " Umpasa in the contex of Toba Batak community is not only beautify the string of words, but also to convey a veri broad meaning, that contains the philosophy of life, ethics of decency, laws , and society". Umpasa and umpama are kind of poetry. Umpasa is a kind of pantun that is four lines verse with alternate rhyming lines. The first two lines are usually allusive. The last two lines have a more direct meaning. Umpama is a kind of witty saying consist of one line which is an illustration which reflect an idea.To find the deep meaning, theory of Taylor Richard $\mathrm{H}$ was used. According to Taylor [9] "Structure and style are the principal devices of poetry and its language is far more codensed and intensified then even that of drama.". Siahaan.Bisuk in his book Kehidupan Di Balik Tembok Bambu [10] gives the definition or concept of a leader of Batak Toba. According to Siahaan,a leader is called raja. That is why, we find many kind of raja among the people such as Raja ni Huta, raja Bondar or Raja Ihutan. Although they are called raja, they are not like the kings in Java or European kingdom. They are leaders or 
heads but they do not have any power like Javanese or European aristocracies. It is more suitable to call them leaders or heads. According to Nasir [11] "The path goal theory of leadership describes clearly that leaders can achieve desired goals and identify the new policies by adopting new leadership style accoding to the situation.To understand organizational effectiveness many researchers and practitioner have develop various studies to determine theories regarding leadership organizational commitment and job satisfaction". According to Nasir (2019:545 CEO Rajeev Peshawarira of ICLIF (Leadership \& Governance Centre Malaysia) has develop a formula for a leadership. According to him," Leadership consist of Charisma, Personality,Power, Authority Skills Competences, Best Practices cognitive Inteligence, Emotional Intelligence" Decades of research suggest that leaders are both born and made. This suggest that environmental factors play a large part in the early development of leader potential and the attainment of leadership positions, but the heredity should also be considered. It has been proposed that a leader development is a process that can be occur across the entire life span and is journey with various development

\section{Research Method}

The research has been conducted based on the fenomenologist pespective, which is a philsofical persfective based on some step of process of thinking through many critical and scientific. Two kinds of research have been conducted, they are library research for collecting umpasa and umpama whereas field research was conducted to find the function of umpasa and umpama and the attitute of the people toward them. After formulating the problem, the main method of research is decided, that is qualitative descriptive.According to Bondan and Taylor [12] The procedur of qualitative research produces a research that reveal qualitative data that through an approach directed to the background and people hollistically or wholly but view it as an unity. The decision to use qualitative descriptive was based on the consideration that this approach enable the research to use strong data analysis in arranging a deep description. Connected with this, some method that applied to collect the data are (1) Method of Documentation to collect umpasa and umpama out of written source such as document,books, journal, notes or news paper. Documentation technic arerecording, noting and taking fotos. (2) Interview to find the reason for the decrease of appreciation of people towards umpasa and umpama and to find solution for the problem by establishing the revitalization. Interview is a meeting of two or more people to change information or ideas through questions and answer so the meaning of a topic can be organized Obsevation to see how are umpasa used .Observation was conducted to see how are umpasa and and umpama used. The method of questionare was used to get self report of the informan. Focussed Group Discussion or FGD was applied to straight the function of umpasa and umpama. Analysing the collected data was conducted by using the theory of Taylor Richard $\mathrm{H}$ to find the meaning within the umpasa and umpama deals with the concept of a leader.According to Richard there are tree device in finding the meaning. They are structural device, sense device which deals with the figurative language and sound device.According to Tampubolon et all [13] " figurative language is a type of language that uses language or phrases different from literal meaning. 7 of 10 kind of figures of speech were found in the umpasa and umpama Batak" 


\section{Results And Discussion}

There are 29 umpasa and umpama had been selected to be the object of the research in finding the concept of Batak Toba of a leader. These data consist of 10 umpasa and 19 umpama. Here below are some of them.

Among the people of Batak Toba the word raja is a term used for a leader. That is why the people have many kinds of raja such as Raja huta means the head of a kampung or raja bondar, a term given to a person who handle irigation whose obligation is to manage the distribution of water. Still, being a raja is honorable position. It can be seen in the below umpasa:

Disi sirunggu kdisi sitata

Sitarungguk is there, Sitata is also there

Ia disi hita hundul, disi omputta Debata

Where ever we sit, God is there, too

This Umpasa means that whatever they (the raja) do, where ever they are ( the raja) God is with them.In another words they have to be serious in doing their duty for the Creator witneses them and they are blessed by God.The qualification that should be possesed by a raja or a leader can be seen in the below umpasa

Hariara na bolon, pangunsandean sihor-sihor

Big banyan is a place for the net to lean on

Sai tubu ma raja,na godang pangidoan uhum na tigor

Wishing a king to be borned, to ask for knowledge and justice

The above Umpasa consist of two lines. The first is called sampiran (alternating rhyming line )which has no connection- based on meaning- to the the second lines which is called isi or content. The qualification of a leader or a raja which is formulated in second line should be a person who has a broad nowledge on law for providing justice.Based on this meaning it can be concluded that a leader or a king is a person who is able to give justice. It can be seen that a leader or raja has a close relationship with the possesion of knowledge . In this case, knowledge deals with law. It means a raja or a leader is a person whose obligation is to judge.The word tigor means straight. It also means just, straight forward or honest. Then , a leader or raja should be a stright forward or a honest person. The decision that he has to give should be a straight forward decision. The word tigor means correct, or right.

Baris-baris ni gaja, di rura Pangaloan

March of elephants are at the valley of Pangaloan

Molo marsuru raja, dae ma so oloan

If the king give the instruction, no reason not to obey

The content reveals a concept that a leader is a person whose instruction is difficult to reject. It can be connected with charisma or power or authority. A leader is a person to look up to. His people or follower will be reluctant to reject him. The above data is umpasa where the first line is sampiran which has no any connection with the meaning or content in the second line that reveal the concept of a leader as a person that people can lean on. The word place to lean on can be connected with the meaning of power. In this case power or authority is not only physical, but it also deals with mental, knowledge and economic potensial. A place to lean on means a place which is strong, powerful to support and to give comfort. We look for something to lean on because there is a need of support that can decrease the weariness and to provide comport. It can be concluded that a leader should be a person who 
has power or outhority to support.He is ready to be a place to lean on and he gives it sincerely so the person who lean on him feels comfortable.

Hauma ni Sitohong pambuatan ni Langki

Fields in Sitohong are places to collect nails

Martua angka raja na so marhilong

Blessed is the king who does not cheat

The second line gives an idea about being a leader. A leader is a person who would not cheat. He is honest and can be trusted. Trust or reliable is a very important qualificationof a leader.A honest king or leader is blessed. The word martua deals with supernatural power. It means blessed by the Creator. The word martua has to be connected to the super natural power. It is nothing to do with human.This Umpasa shows the believe of the people that a honest person will be blessed by the Creator. And for the people honesty is a very important qualification demanded not only by the people but also by the Creator. Honesty is a very important attitute or qualification and there will be reward for it, that is a blessing.

Umpamaas a witty saying. It is a is a sentence that reflects an effort of comparing. Old Indonesian witty saying are pepatah,perumpamaan,ibarat and tamsil . Perumpamaan is a sentence that express a process of comparing (simili), a figure of speech, ibarat is an illustration followed by explanation, tamsilis a figure of speech where the sampiran and content are on the same line adalah kalimat. Based on the theory I.E Richart, umpama is reflective poem. The readers or the listeners are given a picture, an illustration which is the result of a process of comparing.

Di jolo pangihutan di pudi panggomgom

In front to follow, at the back to protect

The umpama above says that a king or a leader is a person who walk in front to follow. It means that a leader is a person that can be imitated.This person is also an individu who is ready to walk at the back or stay at the back, behind the people in order to protect them.

Topot raja ni uhum, sudung raja ni patik

Seea king for justice, see a king for regulation

It reflects the idea of a good leader that is a person who masters law and regulations.To understand law we should see a king or a leader. And to understand regulation we have to see the king or the leader,too. Then we can conclude that a king or a leader is a person who has the knowledge of law and regulation. It is impossible to be a good leader without knowing law and regulation. It means a leader should be a person with a broad knowledge of low and regulation.

Na manghaol bunga,situndali matani ari binsar

Who holds flowers, who turns hisback to the sun rise

This umpama gives an illustration of a leader, flowers and the sun rise. Flower can be found in any kind of literary works as the symbol of beauty. A king or a leader is potrayed as a person who hold flowers, who loves beauty. He must be gentle. It is impossible for a rought person to hold flowers. Then, a raja or a leader should be a gentle person and a person who loves beauty.He is a person who turns his back to the sun rise. Turn his back to the sun rise gives a sense of ignorance. To turn his back to the sun rise means that he takes no notice of the sun rise. The question is why. To turn his back to the sun rise because he want to keep his eyes. And the sun here is something that can hurt his eyes if he stare or focus on it. So what 
the sun rise stand for ?. It shines and also beautiful. A leader holds the flower, still he turns his back to another kind of beauty, the sun rise. Two kinds of beauty. A beauty that give a sense of softness and mild, colorful and it doesn't hurt him. The sun also beautiful still it is painful for it has a power to hurt. Then it is understandable that the sun rise here stand for dangerous beauty. A kind of destructive beauty. To turns his back to the sun rise means that he ignore destructive beauty. A chance to give another interpretation for the sun rise is open. Sun rise could be something that blind eyes such as power or gold or money. Turn his back to the sun rise means ignoring things that could blind his eyes. He prefer the beautful flower to the destructive beauty.

Manolon do raja i naingkon tigor uhum sidabuonna

The king declares an oath, the punishment that he'll execute has to bestraight

There are two words that attract our attention in the above umpama which are needed to analyse. The two words are declaring oath (manolon) and straight punishment (uhum na tigor). Manolon means declaring oath. Declaring oath means if the person ignore, his oath, it is believed that he will be punished by supernatural power. The second is the straight forward punishment(law). It is not a crooked or curved punishment. On a broader sense it means that all the people are on the same position in front of the law. This umpama gives a clue that a leader should be a straightforward person and rightfull or fair.

Na maila sumurut na maila so dapoton

Who feel ashamed to turn back ward and who fells ashamed if he is not available (can't be seen).

The above umpama gives a sense of comparing, that is a leader or a king is a persistent person who does not intend to turn back ward. It will be a stain if a raja or a leader if he turn back from what he has attend to do. It means a raja or a leader should be a person who is not easy to give up. The second is, he would feel ashamed if he is not available when people want to see him. It means a leader is a person that can be seen any time.

Parmahan mantat batahi, pamuro so mantat sior

A sheperd without stick, a person who keep an eye on the padi (rice) on the field with an arrow

The illustration in this umpama is a sheperd. Usually a sheperd has a stick.Still this sheperd is without stick to direct his cattle. This leader which is potrayed as a sheperd doesn't need a stick to direct his people. Another illustration is a person who use arrows when he work on the field keeps padi or rice before the harvest time. It shows that a leader should be a smart person in choosing his weapon.

Si tiop gantang pamonaran na so ra teleng

Who holds the the measure of truth which is not slanting

A raja or a leader is a straigforward person. His measure of truth is the correct measure.

Just like those ideas given by expert which have been mentio before just like "The knwoeledge oriented leadership aligns the objective around those strategies, initiatives, investments which support the organization to cupe up with upcoming digital age challenges" The the analysis reveals the concept of Batak Toba about a leader is that he has to posses nowledge. This qualification found in six umpasa and umpama.The second is the possession of power found in six umpasa and umpama. The third qualification for Batak Toba is that a leader is a person to follow and to imitate. The rest are the emotional inteligence like the 
qualification of fairness (3), wise (2), gentle (2), provide the feeling of secure (2), attentive (1), trustworthiness (1), cooperative (1),generous (1),loving (1), unambitious (1), faithful (1), acceptable (1), effective and consistent (1).

\section{Conclusion}

Mostly, the umpasa and umpama emphasis the concept of leader on having knowledge and power and someone to follow and to obey. Whereas the modern concept stress on having capability and skill to influence and someone to obey. Then it is clear that the concept of traditional Batak Toba still relevant to nowadays modern theory of Information and Communication Technology (ICT).

\section{Acknowledgement}

We would like to express our grateful to Lembaga Penelitian Universitas Sumatera Utara as the financer of the research under the contract no 4167/UN5.1.RPPM/2019 tanggal 01 April 2019 Martha Pardede/Roswita Silalahi

\section{References}

[1] N. Zakaria, A. Nasir, A. Akhtar, and R. Y. Khan, "Are the Leaders Ready to Embrace Industry," J. Adv. Res. Dyn. Control Syst., vol. 11, no. 05 Special Issue, pp. 543-549, 2019.

[2] I. Hilman and N. Sunaedi, "Revitalization of Local Wisdom for the Environmental Education," Conf. lst Int. Cohference Geogr. Educ. (ICGE 2016), vol. 79, no. 1, pp. 383-387, 2016.

[3] Ayatrohaedi, Kepribadian Budaya Bangsa (Local Genius). Jakarta: Pustaka Jaya, 1986.

[4] R. R. Tobing and G. M. Hutabarat, "The traditional settlement architecture of the Bataknese Toba tribe and clan kinship in the village of Hutaginjang, North Sumatra, Indonesia," ISVS Ejournal, vol. 6, no. 2, pp. 12-21, 2019.

[5] H. Samosir, "Metafunction Patterns of the Toba Batak Language," Polyglot J. Ilm., vol. 14, no. 2, pp. 107-124, 2018.

[6] M. M. Sidabutar and F. Mas, "Peran Kepemimpinan Batak ( Studi Eksplorasi pada Ganesha Operation Medan )," Diponegoro J. Manag., vol. 5, no. 2, pp. 1-15, 2016.

[7] A. Reid, "Is There a Batak History?," SSRN Electron. J., no. November 2006, pp. 105-119, 2006.

[8] A. N. Pasaribu, "The Function And Meaning Of Umpasa In Toba Batak's Traditional Wedding The Function And Meaning Of Umpasa In Toba Batak' s Traditional Wedding Ceremony," Int. Conf. ELT, Linguist. Transl., vol. 4, no. 2, pp. 1-10, 2017.

[9] R. Taylor, Understanding The Elements Of Literature: Its Forms, Techniques And Cultural Conventions. London: Macmillan Education UK, 1981.

[10] B. Siahaan, Batak Toba Kehidupan Di Balik Tembok Bambu. Jakarta: Kempala Foundation, 2005.

[11] Z. Liu, R. E. Riggio, D. V. Day, C. Zheng, S. Dai, and Y. Bian, "Leader Development Begins at Home: Overparenting Harms Adolescent Leader Emergence,” J. Appl. Psychol., pp. 1-17, 2019.

[12] L. J. Moleong, Metodologi Penelitian Kualitatif. Bandung: Remadja Karya, 1989.

[13] M. Tampubolon, "Figurative Language in the Toba Batak Saur Matua Ceremony," Linguist. Terap., vol. 14, no. 2, pp. 122-131, 2017. 
